\title{
RESISTENSI DAN RESPON ETNIK AFRO-AMERIKA ATAS MARJINALISASI ETNIK ANGLO-AMERIKA DALAM PUISI-PUISI KARYA HUGHES
}

\author{
Sugi Iswalono \\ FBS Universitas Negeri Yogyakarta \\ e-mail: sugi_iswalono@uny.ac.id
}

\begin{abstract}
Abstrak
Penelitian ini bertujuan mendeskripsikan bentuk dan respon terhadap hegemoni rasial serta jati diri etnik Afro-Amerika dalam puisi karya Hughes. Penelitian menggunakan pendekatan deskriptif kualitatif. Sumber data adalah puisi karya Hughes berjudul "I, Too, Sing America", "Let America be America Again", dan "Theme for English B". Data dianalisis berdasarkan teori postkolonialisme dan diperkaya informasi sejarah, sosialbudaya, dan politik pada masa pasca perang saudara sampai tahun 1960-an di Amerika Serikat. Hasil penelitian sebagai berikut. Pertama, hegemoni rasial muncul dalam bentuk stereotyping negatif terhadap etnik Afro-Amerika. Stereotype negatif mengarah pada marjinalisasi terhadap etnik Afro-Amerika yang tercermin dalam ketidakadilan dan kesewenangan oleh etnik mayoritas. Kedua, respon atas hegemoni rasial berupa kesadaran etnik Afro-Amerika akan martabat, harga diri, dan kepercayaan diri sebagai pijakan menuntut kesetaraan dan menunjukkan eksistensi di tengah dominasi etnik kulit putih. Ketiga, kebanggaan jati diri etnik sesungguhnya merupakan potensi dalam mewujudkan cita-cita Amerika sebagai negara yang mengedepankan kesetaraan dalam kemajemukan sebagaimana diidamkan oleh para pendiri bangsa.
\end{abstract}

Kata kunci: Afro-Amerika, hegemoni, marjinalisasi, prasangka rasial, jati diri etnik

\section{THE AFRO-AMERICAN ETHNIC GROUP'S RESISTANCE AND RESPONSES TO THE MARGINALIZATION BY THE ANGLO-AMERICAN ETHNIC GROUP IN HUGHES'S POEMS}

\begin{abstract}
This study aims to describe the forms of and responses to racial hegemony and the Afro-American ethnic group's self-identity in Hughes's poems. It employed the qualitative descriptive approach. The data sources were Hughes's poems entitled "I, Too, Sing America", "Let America be America Again", and "Theme for English B". The data were analyzed by means of the postcolonialism theory, enriched by historical, socio-cultural, and political information during the post-civil-war era till 1960s in the United States of America. The findings are as follows. First, racial hegemony appears in the form of the negative stereotype of the Afro-American ethnic group. The negative stereotype leads to the marginalization of the Afro-American ethnic group, reflected by the injustice and tyranny by the majority ethnic group. Second, responses to racial hegemony are manifested in the Afro-American ethnic group's awareness of dignity, self-esteem, and self-confidence as foundations to demand equality and to show their existence amid the white people ethnic group's domination. Third, the pride of ethnic identity is actually a potential to realize Amerian ideals as a nation highly respecting equality and diversity as aspired by the founding fathers.
\end{abstract}

Keywords: Afro-American, hegemony, marginalization, racial prejudice, ethnic self-identity

\section{PENDAHULUAN}

Sastra sebetulnya merupakan menifestasi jatidiri bangsa, sebagaimana perja- lanan politik Obama dalam meraih kursi kepresidenan yang sebetulnya juga merupakan tontonan jatidiri Amerika. Berkaitan 
dengan hal ini, Darma (1993:242-3) mengatakan bahwa jatidiri merupakan sistem dan oleh karenanya mempunyai jaringan sistem yang salah satunya adalah sastra. Sementara itu, jatidiri sangat terkait dengan dinamika internal kehidupan bangsa. Makin kokoh persatuan dan kesatuan suatu bangsa, makin kokoh pula kebudayaan bangsa tersebut; kebudayaan yang kokoh akan mengkokohkan jatidiri, jatidiri yang kokoh akan mengkokohkan sastra. Selanjutnya, Darma mengatakan bahwa kokohnya persatuan dan kesatuan bangsa, sadar atau tidak sadar, akan mengakibatkan para pengarang merumuskan jatidiri masing-masing. Tentu saja, terutama, hal ini erat berkaitan dengan negara-negara multikultural seperti Indonesia, Australia atau Amerika.

Pengarang yang dimiliki oleh negaranegara dilahirkan dan ditumbuhkembangkan oleh sub-kebudayaan tertentu sehingga terbentuklah pengarang nasional yang sekaligus pengarang dari sub-kebudayaan tertentu. Namun demikian, dikotomi ini, menurut Darma, justru makin memperkokoh persatuan dan kesatuan bangsa dan pada gi-lirannya makin memperkokoh sastra yang dihasilkan oleh bangsa-bangsa tersebut. Sastra nasional Amerika, misalnya, diperkuat oleh pengarang-pengarang yang berasal dari berbagai etnik yang membentuk subkebudayaan-sub-kebudayaan tertentu. Sub-kebudayaan Afro-Amerika disuarakan oleh 'etnik' Afrika yang telah menjadi warga negara Amerika. Dengan demikian, kelompok etnik ini juga menyuarakan jatidiri mereka.

Penelitian ini memfokuskan pada tiga puisi yang berjudul "I, Too, Sing America", "Let America be America Again", dan "Theme for English B" karya Hughes. Alasan pemilihan atas karya-karya ini adalah bahwa karya-karya ini sudah bisa mewakili 'nilai-nilai' zaman sebagaimana dialami oleh etnik Afro-Amerika pada waktu karya-karya ini dipublikasikan.
Etnik kulit putih Amerika (etnik AngloAmerika) mampu membangun hegemoni diri mereka atas ras kulit hitam (dalam konteks ini, etnik Afro-Amerika) antara lain melalui pencitraan dalam karya sastra yang mereka hasilkan. Mereka mencitrakan diri mereka sebagai etnik superior yang memarjinalkan ras kulit hitam sebagai etnik inferior. Hughes merespon konstruksi sosial-budaya yang bersifat hegemoni ini lewat ketiga puisi di atas.

Huges lewat "Let America be America Again", dan "Theme for English B" menyuarakan tentang kemerdekaan dan kesetaraan serta pengakuan sebagai warga Amerika sebagaimana yang telah dideklarasikan oleh the founding fathers of America itu sendiri. Sementara itu, lewat "I, Too, Sing America" Hughes mulai menunjukkan rasa percaya diri sebagai warga Amerika yang mempunyai peran sebagaimana warga Amerika yang lain meskipun etnik Afro-Amerika seperti dia masih mengalami stereotip negatif.

Selanjutnya, yang dimaksudkan dengan para penulis/pengarang di sini adalah para penulis sastra (Inggris) postkolonial Amerika dari etnik Afro-Amerika yang menulis karya-karya mereka dalam bahasa Inggris tetapi dalam karya-karya yang mereka hasilkan sama sekali tidak merepresentasikan sudut pandang kelompok mayoritas Amerika (baca AngloAmerika = the main stream culture). Penulis ini adalah warga negara yang merdeka tetapi masih 'termarjinalkan' oleh kekuasaan etnik Anglo-Amerika. Dengan kata lain, karya sastra yang menjadi subyek penelitian ini adalah karya sastra Inggris yang sarat dengan muatan budaya etnik yang 'terjajah' atau 'termarjinalkan', yaitu etnik Afro-Amerika.

Istilah 'semangat zaman' berasal dari bahasa Jerman zeitgeis yang merupakan gabungan dari kata zeit dan geist (Kohl, 1992:151-2). Kata geist secara umum bisa diartikan 'semangat' meskipun yang dimaksud dengan semangat disini me- 
ngacu pula pada semangat berpikir yang meliputi aspek pengalaman kultural dan intelektual yang melebihi batas-batas orang perorangan yang termanifestasikan dalam semua aspek pengalaman manusia termasuk didalamnya, tentu saja, pengalaman bersastra. Sementara itu, kata zeit berarti periode waktu dalam sejarah.

Berdasarkan uraian singkat ini, istilah 'semangat zaman' dalam konteks penelitian ini adalah periode waktu tertentu dalam sejarah kehidupan bangsa Amerika. Dari kacamata etnik Afro-Amerika secara umum disebut Harlem Renaissance yang dalam kurun ini terdapat semangat besar dari etnik Afro-Amerika untuk menunjukkan jatidiri budaya mereka. Dalam bidang sastra para penulis 'subaltern' ini mengungkit-ungkit isu-isu 'nasionalisme' serta mencoba memaparkan perlakuan yang mereka alami dari etnik AngloAmerika, etnik yang dominan di negara mereka tinggal.

Poskolonialisme didefinisikan sebagai sebuah pendekatan dalam analisis sastra yang memfokuskan pada karya sastra yang dihasilkan oleh negara-negara yang pernah dijajah oleh bangsa-bangsa Eropa. Karya sastra yang dihasilkan kelompokkelompok etnik tertentu yang ketika karya tersebut dipublikasikan masih termajinalkan oleh etnik lain yang lebih berkuasa, dalam hal ini biasanya oleh etnik Eropa. Dalam konteks penelitian ini adalah etnik Anglo-Amerika.

Wacana postkolonial dan postkolonialisme pertama kali diperkenalkan secara tegas, jelas, dan komprehensif pada tahun1989 oleh Ashcroft, Griffiths dan Tiffin dalam buku mereka yang berjudul The Empire Writes Back: Theory and Practice in Post-Colonial Literatures. Pada tahun 1990, Adam dan Tiffin menyusul karya besar ini dengan menerbitkan Past The Last Post: Theorizing Post-Colonialism dan Post-Modernism. Pada pertengahan tahun 90-an, istilah-istilah itu telah secara tegas digunakan di dalam tulisan-tulisan aka- demik, meskipun jika dirunut kebelakang lagi yang membidani lahirnya kritik sastra postkolonial adalah Said dengan karya monumentalnya Oreintalism (1978). Dewasa ini, istilah postkolonialisme, seperti telah disinggung di atas, biasanya mengacu pada karya sastra yang dihasilkan oleh budaya dari negara-negara bekas jajahan Inggris Raya (Anglo Saxon).

Apapun definisi postkolonialisme, menurut Bressler (1999: 266), pada dasarnya postkolonialisme berkaitan dengan berbagai macam isu yang dengan jelas diterangkan buku yang diedit oleh Ashcroft, Griffiths, dan Tiffin yang berjudul "The Post-Colonial Studies Reader" yang pertama kali terbit pada tahun 1995, yang di dalamnya terdapat berbagai macam pandangan mengenai postkolonialisme. Dalam buku ini, kutip Bressler, subyek-subyek yang dibicarakan antara lain mengenai universalisme, perbedaan, nasionalisme, postmodernisme, representasi dan resistensi, kesukuan, feminisme, bahasa, pendidikan, sejarah, tempat dan produksi. Meskipun sangat banyak perbedaan yang muncul, semuanya mengacu pada satu hal yang menjadi perhatian postkolonialisme, yaitu menegaskan perjuangan yang muncul sebagai akibat dari didominasi suatu budaya terhadap budaya lainnya.

Karena budaya kaum yang terjajah/ termarjinalkan ini berbeda dengan budaya 'mainstream, budaya mereka ini ditekan, ditaklukkan, dan seringkali dihilangkan dari sejarah. Fakta ini serta merta akan menimbulkan reaksi terhadap budaya penjajah dengan cara yang berbeda-beda. Maka dalam teori postkolonial berkembang tidak hanya satu teori dan metode yang bisa digunakan, yang secara garis besar, menurut Ashcroft (dkk) (1989:15) bahwa dalam sastra postkolonial terdapat empat model, yaitu model 'national or regional models', 'Black writing model', 'comparative model' dan 'more comprehensive comparative models'. Meskipun setuju dengan pendapat Ashcroft (dkk), 
Gandhi (2001:vi) menegaskan bahwa model pertama dan kedua merupakan model penting dalam sastra postkolonial. Oleh karena itu, dua kunci utama dalam memahami sastra dan teori psotkolonial adalah memahami dominasi-subordinasi dan hibriditas-kreolisasi. Penelitian ini akan memanfaatkan model yang kedua, 'Black writing', yang lebih menekankan masalah etnisitas ketimbang nasionalitas sebagaimana yang terjadi dalam sastra Afro-Amerika dengan memanfaatkan pendapat Bressler dalam Literary Criticism: An Introduction to Theory and Practice sebagai alat analisanya.

Minat yang berkembang atas postkolonialisme dalam teori sastra Amerika, menurut Bressler (1999:268), terjadi sekitar akhir 1970-an sampai dengan sekarang dengan memberikan perhatian pada para penulis Afro-Amerika dan karyakaryanya. Perhatian para sastrawan ini banyak dicurahkan pada hubungan antara seni, seperti fiksi, musik, dan teater, dan perkembangan pemahaman karakteristik budaya Afro-Amerika. Pada masa tersebut, penulis seperti Langston Hughes, Richard Wright, Zora Neale Hurston, James Baldwin, dan Ralph Ellison menghasilkan karya-karya yang menggambarkan bagaimana orang-orang Afro-Amerika berinteraksi dengan budaya mereka.

Selanjutnya, masih menurut Bressler, dalam karya sastra yang mereka hasilkan, para penulis ini mencurahkan perhatian mereka padaisu-isu nasionalisme dan mencoba memaparkan bagiamana budaya 'mainstream' kulit putih, memperlakukan budaya etnik Afro-Amerika sebagai subbudaya yang tertindas, tertekan, dan termarjinalkan. Dengan menampilkan tematema yang bervariasi, para penulis AfroAmerika ini melakukan pencarian jatidiri melalui getirnya perjuangan mereka untuk mencapai keberhasilan dalam bidang politik, ekonomi, dan sosial.

Berakhirnya Perang Saudara di Ame- rika Serikat merupakan fase sejarah yang sangat penting bagi warga kulit hitam Amerika. Bersamaan dengan berakhir-nya perang tersebut "berakhir" pulalah masa perbudakan atas diri mereka. Lambat laun banyak warga Afro-Amerika ini yang berpindah ke Amerika Serikat bagian utara. Namun demikian, mereka masih mengalami diskriminasi rasial terlepas dari adanya penghapusan perbudakan yang telah dicanangkan pemerintah kulit putih Amerika. Diskriminasi ini terjadi hampir di semua aspek kehidupan mereka meskipun mereka juga telah mendapatkan beberapa kesempatan untuk maju dikarenakan tersedianya kesempatan untuk mendapatkan pendidikan dan pekerjaan yang layak.

Tahun 1920-an muncullah kesadaran akan identitas/jati diri mereka sebagai etnik Afro-Amerika dan kebanggaan atas diri mereka itu. Bersamaan dengan itu, terbentuk pula apa yang dinamakan NAACP (National Association for the Advancement of the Colored People) di New York. Organisasi ini dimanfaatkan oleh para intelektual dan pemimpin etnis kulit hitam Amerika sebagai sarana untuk menyuarakan ketidakpuasan mereka atas makin maraknya kekerasan terjadi pada warga Afro-Amerika (Rhodes, 2012:par.12).

Pada sekitar tahun ini pula muncul konsep "The New Negro", antologi yang diterbitkan pada tahun 1925 di bawah editor Alain Locke ("New Negro", 2012: par 12). Menurut Locke The New Negro yang merupakan simbol kulminasi tahap pertama dari The New Negro Renaissance dalam bidang sastra harus mampu mendokumentasikan The New Negro secara sosial dan budaya, yaitu merekam semua transformasi kehidupan lahir-batin warga kulit hitam Amerika yang secara signifikan telah terjadi dalam kehidupan mereka di negara ini. Oleh karena itu, masa ini dikenal sebagai The "New Negro Movement" yang kemudian lebih terkenal dengan sebutan Harlem Renaissance ("Harlem 
Renaissance", 2012: par.1). Gerakan budaya Afro-Amerika ini berpusat di lingkungan Harlem di New York.

Tidak ada gaya penulisan yang menjadi karakteristik pada gerakan ini. Namun secara garis besar gerakan ini merupakan kebanggaan etnis Afro-Amerika yang melalui karya sastra, seni, dan musik digunakan untuk menentang rasisme dan stereotyping dan meningkatkan integrasi sosial-politik serta politik sosialis yang progresif ("Harlem Renaissance", 2012: par.14). Sementara itu, secara umum tema pada masa ini adalah dampak pengalaman perbudakan dan munculnya identitas Afro-Amerika sebagai warga kulit hitam Amerika, dampak rasisme yang telah melembaga, dilema dalam mementaskan serta menulis karya sastra bagi masyarakat kulit putih Amerika, dan serangkaian permasalahan tentang bagaimana cara menggambarkan pengalaman kehidupan modern mereka di kota-kota Amerika Serikat bagian utara ("Harlem Renaissance", 2012:par. 16).

\section{METODE}

Penelitian ini merupakan penelitian kajian pustaka dan bersifat deskriptif kualitatif. Sumber data penelitian adalah tiga puisi karya Langston Hughes yang berjudul "I, Too, Sing America", "Let America be America Again", dan "Theme for English B". Dengan menerapkan teori postkolonial, penelitian ini bertujuan untuk menemukan, memaparkan, dan menganalisa tiga hal: 1) bentuk-bentuk hegemoni rasial yang terdapat dalam ketiga karya Hughes tersebut, 2) respon etnik Afro-Amerika atas hegemoni rasial etnik Anglo-Amerika atas keberadaan mereka, dan 3) jati diri etnik Afro-Amerika yang mereka suarakan lewat karya-karya tersebut di atas.

Penelitian ini menggunakan data yang berupa kata atau ekspresi-ekspresi yang ada di dalam karya. Untuk mendapatkan tambahan informasi mengenai isu tersebut, dikumpulkan data dari berbagai sumber pustaka yang lain terutama bukubuku mengenai postkolonialisme dan buku-buku yang memaparkan mengenai sejarah, sosial-budaya, dan politik etnik Afro-Amerika. Yang menjadi buku acuan utama untuk analisis adalah Literary Criticism: An Introduction to Theory and Practice karya Charless E. Bressler. Latar belakang sejarah, sosial-budaya, dan politik yang berkaitan dengan Harlem Renaissance, the New Negro Movement dan ketiga penulis tersebut diambil dari berbagai sumber tercetak maupun internet.

\section{HASIL DAN PEMBAHASAN}

Penelitian ini menggunakan teori postkolonial untuk memaparkan dan menganalisa bentuk-bentuk hegemoni rasial etnik Anglo-Amerika terhadap etnik AfroAmerika sebagaimana yang tersembunyi dalam teks sastra karya Hughes yang berjudul "I, Too, Sing America", "Let America be America Again", dan "Theme for English B". Teks-teks ini sebetulnya juga merupakan respon dari etnik Afro-Amerika atas hegemoni etnik Anglo-Amerika atas semua aspek kehidupan yang mereka jalani. Dengan demikian, respon ini membongkar citra etnik Anglo-Amerika sebagai etnik superior sebagaimana terepresentasikan lewat teks sastra mereka yang merupakan teks mainstream di Amerika. Perlawanan etnik Afro-Amerika ini menunjukkan bahwa etnik Anglo-Amerika yang dicitrakan sebagai etnik superior ini hanyalah merupakan mitos. Perlawanan yang mereka sampaikan lewat teks-teks ini sekaligus juga merupakan pemaparan jati diri mereka sebagai etnik minoritas.

\section{Bentuk-Bentuk Hegemoni Rasial}

Bentuk-bentuk hegemoni rasial yang dialami dan kemudian direpresentasikan dalam karya puisi paling tidak mempunyai kaitan yang erat dengan apa yang disebut sebagai 'institutionalized racism' yaitu kebijakan dan praktek rasis yang direka- 
yasa oleh penguasa etnik Anglo-Amerika dalam pranata kehidupan masyarakat. Rekayasa tersebut tampak dalam bidang pendidikan, pemerintahan federal dan negara bagian, bidang hukum, baik yang tertulis maupun implementasinya, bidang kesehatan yang memberikan pelayanan kesehatan dan pengalokasian dana yang tidak adil terhadap etnik minoritas seperti etnik Afro-Amerika(Tyson, 2006:361). Berdasarkan analisa atas teks-teks tersebut, bentuk hegemoni rasial yang merupakan diskriminasi ditemukan dalam dua katagori besar, yaitu stereotyping dan marjinalisasi.

\section{Stereotyping}

Bentuk hegemoni stereotype bisa ditemukan pada dua puisi Hughes, "I, Too, Sing America" dan "Theme for English B". Kedua puisi tersebut menggambarkan diskriminasi rasial yang dilakukan oleh mayoritas masyarakat kulit putih terhadap etnik kulitg hitam.

Diskriminasi rasial sebagaimana yang diungkapkan oleh Hughes lewat puisinya yang berjudul "I, Too, Sing America" tercermin dalam stereotyping terhadap etnik kulit hitam yang diterima sebagai kebenaran oleh masyarakat Amerika, terutama di antara warga kulit putih. Diskriminasi ini dihidupkan lewat institutionalized ra-cism yang menekankan bahwa standar 'beauty' adalah 'Anglo-Saxon beauty' (Tyson, 2006: 362) yang berkulit putih, berhidung mancung, dan berbibir tipis yang merupakan salah satu ciri utama etnik Anglo-Saxon. Karena mereka tidak memenuhi standar 'Anglo-Saxon beauty', etnik minoritas kulit hitam ini tidak diterima sebagai 'brother' oleh kelompok etnis mayoritas. Oleh karena itu, mereka pun dianggap tidak sederajat oleh kelompok mayoritas ini. Sebagai konskuensinya, mereka mengalami marjinalisasi sosial-budaya dalam perikehidupan mereka sebagai warga negara Amerika. Mereka hidup sebagai warga inferior dalam negara mereka sendiri.
...I am the darker brother.

They send me to eat in the kitchen

When company comes.

(baris 1-3)

Dalam ketiga baris dari puisi "I, Too, Sing America" ini, berdasarkan akan kesadaran sebagai warga negara, meskipun si aku lirik menganggap dirinya sebagai 'brother' warga kulit putih. Etnik mayoritas masih tidak mau menerima bahwa mereka adalah sama-sama warga negara yang mempunyai kedudukan yang sama. Penggunaan ekspresi "They send me to eat in the kitchen/ When company comes." merupakan ungkapan metaforik bagaimana mereka masih dimarjinalkan. Makan bersama di meja yang sama secara figuratif menyiratkan adanya kesetaraan. Namun demikian, si aku lirik harus diusir untuk makan di dapur ketika seorang tamu datang. Si aku lirik yang berkulit hitam ini tidak diterima sederajat dengan mereka.

Pengingkaran etnis Afro-Amerika sebagai bagian dari kehidupan mereka berarti pengingkaran pula terhadap eksistensi etnis Afro-Amerika. Sebetulnya secara de facto dan de jure etnik tersebut telah menjadi warga Amerika sejak dideklarasikannya kemerdekaan Amerika, yang antara lain oleh the founding fathers ditegaskan bahwa "all men are created equal." Hegemoni budaya terhadap kelompok minoritas melalui stereotyping ini menempatkan etnik kulit hitam sebagai warga yang tidak berkelas.

Selanjutnya, Si Aku lirik dalam "Theme for English B" adalah seorang mahasiswa kulit berwarna berumur dua puluh dua tahun. Warna kulit inilah yang membuat dia mengalami stereotyping dan akibatnya tidak diterima di antara etnik mayoritas Amerika yang berkulit putih. Ia mengalami marjinalisasi sosial. Dia merupakan satu-satunya mahasiswa kulit berwarna dan paling tua di antara teman-teman kuliah. 
Jelas bahwa si Aku lirik, bukan penyair puisi ini tetapi ia diciptakan oleh Hughes untuk menyuarakan hatinya. Menurut Rukhaya (2012: par. 2) Hughes dilahirkan dan dibesarkan di Joplin, Missouri dan kuliah di Columbia University. Si Aku lirik dalam puisi ini dilahirkan di Winston-Salem dan kuliah di City College di New York, manhattan. Rampersad, seperti yang dikuitp oleh Rukhaya, mengatakan bahwa Hughes menulis puisi ini ketika ia mengunjungi City College ini.

Dalam puisi ini si Aku lirik diberi pekerjaan rumah oleh dosennya untuk menulis esai tentang dirinya dan apa yang ia rasakan sebagai dirinya sendiri.

\section{The instructor said,}

Go home and write

a page tonight

And let that page come out of you-

Then, it will be true.

(baris 1-5)

Sebagai satu-satunya mahasiswa kulit hitam dan secara usia paling senior di antara mahasiswa lainya yang berkulit putih, cukup sulit baginya untuk mengungkapkan apa yang harus dia tulis. Kondisi fisik dan psikologis dia kiranya yang membuat dia ragu tentang kebenaran yang akan tulis. Inilah sebabnya dia mengatakan bahwa hal ini tidak sesederhana yang orang lain dipikirkan.

I wonder if it's that simple?

I am twenty two, colored, born in Winston-Salem.

I am the only colored student in my class.

(baris 6-7 \& 10)

Kedua belah pihak etnis yang berbeda ini tidak mau menyatu sebagai kesatuan warga. Meski pun antara dia dan temanteman kulit putihnya, termasuk dosennya, mempunyai kesamaan hakiki sebagai manusia, dan dalam realitanya tidak mungkin terpisahkan dalam kehidupan mereka, paling tidak sebagai warga Amerika.

Well, I like to eat, sleep, drink, and be in love.

I like to work, read, learn, and understand life.

I like a pipe for a Christmas present, or records-Bessie, bop, or Bach.

\section{You are white-}

yet a part of me, as I am a part of you.

That's American.

(baris 21-4 \& 31-3)

Namun kenyataan hidup yang dia hadapi sebagai etnis kulit berwarna tetap menimbulkan pengalaman getir tersendiri bagi si Aku lirik, yaitu masalah kesulitan sebagai warga minoritas di antara etnis mayoritas kulit putih.

I guess being colored doesn't make me NOT like

the same things other folks like who are other races.

So will my page be colored that I write?

Being me, it will not be white.

Sometimes perhaps you don't want to be a part of me.

Nor do I often want to be a part of you.

(baris 25-8 \& 34-5)

Setelah seharian berada di kamarnya untuk mencoba menulis esai, ia justru menghasilkan sebuah puisi.

up to my room, sit down, and write this page:

This is my page for English $B$.

(baris 15 \& 42)

Apa yang dilakukan Hughes melalui si Aku lirik ciptaannya yang menghasil- 
kan puisi dan bukannya esai ini tampaknya dengan sadar ia lakukan. Meskipun zamannya tidak relevan, nenek moyang etnis Afro-Amerika pernah mendapat stigma sebagai bangsa yang tidak beradab. Seperti apa yang dikatakan oleh Tyson (2006:364) bahwa bangsa kulit putih Amerika menganggap bangsa kulit hitam yang mereka kapalkan dari Afrika, termasuk keturunannya yang dewasa ini menjadi etnik Afro-Amerika yang dalam puisi ini direpresentasikan oleh si aku lirik. Mereka tidak bisa dikatagorikan sebagai manusia seutuhnya karena mereka tidak bisa menulis puisi. Tentu saja, pengalaman ini merupakan trauma masa lalu yang masih membekas di hati Hughes. Lebih jauh Tyson mengatakan bahwa hasil karya sastra etnik kulit hitam yang diterbitkan memerlukan kata pengantar dari pakar yang berasal dari etnik kulit putih untuk memberikan testimoni pada penulis dan otentisitas pada karya sastra yang dihasilkan. Hal inilah yang masih menjadi masalah bagi penulis Afro-Amerika. Karya-karya penulis dari kelompok etnis ini berisi perlawanan mereka terhadap hegemoni yang mereka alami. Dalam konteks ini jelas bahwa etnik Afro-Amerika mengalami stereotyping. Mereka masih mendapatkan stigma sebagai etnik yang 'inferior', dan karena inferior mereka ditempatkan sebagai etnik 'independent' yang memerlukan bantuan dari etnis kulit putih. Karya mereka perlu legalitas dari etnik mayoritas yang memarjinalkan mereka.

\section{Marjinalisasi}

Seperti halnya yang disampaikan dalam puisi-puisinya yang lain atau seperti halnya tulisan-tulisan etnik Afro-Amerika yang lain, dalam puisi yang berjudul "Let America be America Again" Hughes menggambarkan nasib etnik minoritas Afro-Amerika, dan etnik minoritas lainnya, yang mengalami marjinalisasi. Marjinalisasi ini ditunjukkan dengan jelas lewat ketidakadilan yang dialami oleh etnik kulit hitam yang direpresentasikan lewat tokoh ciptaan Hughes dalam memperoleh hak warga negara yang sama seperti yang dapat diperoleh oleh etnik mayoritas kulit putih. Di samping itu, marjinalisasi atau diskriminasi sosial ini dengan tegas pula ditunjukkan oleh si aku lirik. Hal yang dipermasalahkan adalah pengingkaran janji yang diberikan oleh para pendiri bangsa ini kepada warga negaranya, bahwa Amerika merupakan negeri impian dan tanah air yang menjamin kebebasan.

... the dream the dreamers dream-

Where never kings connive nor tyrants scheme

(baris 6 \& 8),

............ land where Liberty

Is crowned with no false patriotic wreath, But opportunity is real, and life is free, Equality is in the air we breathe. (baris 11-4).

Dalam kenyataannya tidak semua warga negara mendapatkan janji tersebut sebagimana halnya kelompok etnik tertentu yang mendapat stigma sebagai etnik inferior seperti etnik Afro-Amerika. Janji yang disampaikan oleh founding father itu diingkari oleh generasi penerus bangsa.

(There's never been equality for me, Nor freedom in this "homeland of the free.) (baris 15-6)

I am the man who never got ahead, The poorest worker bartered through the years."

(baris 37-8).

Lebih tragisnya lagi, negara yang pada awal berdirinya menawarkan kebebasan dan impian bagi semua yang menjadi warga negaranya bahkan berbuat sebaliknya. 
Etnis minoritas ini menerima perlakuan yang tidak manusiawi. Ketika gaji tidak diberikan dan mereka protes dengan melakukan mogok kerja, mereka akan dihabisi.

The millions shot down when we strike? The millions who have nothing for our pay?

(baris 54-5).

Impian yang merupakan satu-satunya harapan yang mereka dapat andalkan sudah tidak mungkin tercapai lagi.

For all the dreams we've dreamed

And all the songs we've sung

And all the hopes we've held

And all the flags we've hung,

The millions who have nothing for our pay-

Except the dream that's almost dead today. (baris 56-61)

Judul puisi ini sudah menunjukkan akan adanya pengikaran janji yang telah diberikan pada waktu negara ini didirikan. Hughes merasakan bahwa Amerika saat ini bukanlah Amerika yang seperti yang dijanjikan dahulu. Oleh karena itu, ia menginginkan Amerika kembali ke jati dirinya, yaitu kembali ke Amerika yang setiap warganya mimpikan, "Let America be America Again". Kata 'again' ini digunakan secara efektif untuk menekankan bagaimana Amerika itu seharusnya ("Let America Be America Again Summary", 2013: par.2). Negara merdeka yang memberikan kebebasan warganya untuk mendapatkan segala impiannya. Hal ini lebih ditegaskan dalam bait pertama.

Let America be America Again.

Let it be the dream it used to be.

Let it be the pioneer on the plain

Seeking a home where he himself is free. (baris 1-4)
Sementara itu, si aku lirik tidak mendapatkan seperti yang ia harapkan dari Amerika, "America never was America to me." (baris 5).

\section{Respon Etnik Afro-Amerika atas Hege- moni Rasial Etnik Anglo-Amerika}

Berbagai persoalan yang dialami oleh kelompok Afro-Amerika yang terpinggirkan sebagai akibat hegemeni rasial etnik Anglo-Amerika atas keberadaan mereka, baik dalam bentuk marjinalisasi, segregasi, stereotype, maupun prasangka rasial oleh kelompok mayoritas tentunya mendapatkan respon dari kaum AfroAmerika. Secara garis besar respon yang diberikan berupa adanya kesadaran akan martabat dan harga diri, serta kepercayaan diri kaum Afro-Amerika, yang menjadi dasar akan eksistensi mereka di masyarakat yang didominasi kulit putih.

Puisi "I, Too, Sing America" merupakan respon atas hegemoni budaya yang berupa stereotyping atas etnik kulit hitam Afro-Amerika dan sekaligus merupakan respon atas impian Walt Whitman lewat puisinya yang berjudul "I Hear America Singing" (Kaat, 2013: par.2).

Seperti halnya bangsa Indonesia dan mungkin bangsa lainnya, bangsa Barat (Amerika) juga membagi waktu makan mereka menjadi tiga: sarapan pagi, makan siang, dan makan malam, yang dalam bahasa Inggrinya disebut 'breakfast', 'lunch', dan 'dinner'. Namun demikian berbeda dengan tradisi makan bangsa Indonesia, makan malam merupakan saat makan yang lebih spesial dibandingkan keduanya. Pada saat makan malam biasanya keluarga bersatu dalam satu meja sembari berceritera kejadian yang mereka alami seharian, atau mencurahkan isi hati mereka tentang segala problema yang mereka alami. Dengan demikian terjadilah suasana diskusi di meja makan; mereka saling memberi solusi atas problem yang dihadapi oleh yang lain. Suasana keakraban dan kesetaraan terlihat jelas 
pada saat makan malam ini. Kedekatan pada saat makan malam ini tidak hanya terjadi dalam sebuah keluarga, namun bisa pula terjadi antara kerabat atau teman dekat atau teman biasa yang tidak terlalu dekat sehingga muncul pula istilah 'dinner party'. Hal ini tidak terjadi pada etnik kulit hitam. Meskipun mereka tidak diterima, si aku lirik yang berkulit hitam tetap mempunyai harga diri, rasa bangga sebagai warga Amerika dari etnik lain.

\author{
They send me to eat in the kitchen \\ When company comes, \\ But I laugh, \\ And eat well, \\ And grow strong. Tomorrow, \\ I'll be at the table \\ When company comes. \\ Nobody'll dare \\ Say to me, \\ "Eat in the kitchen," \\ (baris 2-11)
}

Rasa bangga sebagai etnik minoritas ditunjukkan oleh kebersediaan dia tanpa rasa marahuntukmenuruti perintah si tuan kulit putih untuk makan di dapur kapan saja ada tamu. Dia punya rasa optimisme yang besar bahwa dia pun mempunyai keunggulan yang sama dengan tuannya yang berkulit putih. Bahkan ia menertawakan perintah tersebut yang berarti bahwa ia menganggap enteng perintah yang bersifat rasis tersebut, dan kemudian di dapur ia dengan suka-cita makan sekenyang-kenyangnya. Pemenuhan nutrisi ini akan membuat ia tumbuh menjadi sosok yang tegap dan kuat, dan pada suatu saat nanti ia pun akan bisa makan semeja dengan si kulit putih tanpa ada yang berani mengusirnya lagi.

Secara figuratif hal ini berarti bahwa etnik kulit hitam secara sadar mempunyai kualitas yang sama seperti halnya etnik kulit putih. Hanya saja saat kesetaraan yang mereka impikan ini belum tiba. Suatu saat nanti pasti impian ini terwujud.
Munculnya artis kulit hitam sepeti Nat King Cole, Louis Armstrong, dan Sydney Poiter memberikan jalan bagi munculnya tokoh kulit hitam lain ke panggung kehidupan Amerika. Puncak impian mereka adalah terpilihnya Obama sebagai presiden Amerika.

Dengan penuh optimisme dan rasa patriotisme Whitman mengatakan bahwa bangsa Amerika, secara implisit termasuk semua etnik minoritas Amerika yang merupakan bagian dari warga Amerika, telah kuat bersatu-padu sebagai bangsa yang utuh. Hal itu ditunjukkan oleh nilai kebersamaan yang mereka miliki untuk bersama-sama menyanyikan lagu yang memuji Amerika yang akan membawa semua warganya ke arah kehidupan yang lebih baik seperti yang mereka idamkan: "Those of mechanics.../The carpenter.../The mason.../The boatman../The shoemaker.../ The woodcutter's..., the ploughboy's.../... the mother or of the young wife at work, / or of the girl sewing or washing/ are singing "their strong melodious songs." (Whitman, 2013: par.1). Hughes pun mengatakan "I, Too, Sing America". Penggunaan kata keterangan 'too' untuk menegaskan apa yang dilakukan si Aku lirik, yaitu ikut menyanyikan Amerika. Ironisnya, meskipun si aku lirik sadar sebagai warga yang ikut menyanyikan Amerika, ia masih termajinalkan, tidak seperti apa yang diyakini oleh Whitman.

Selajutnya, dalam puisi "Let America be America Again", Hughes menggambarkan reaksi atas diskrimnasi sosial yang dijalankan oleh etnik kulit putih. Etnik kulit hitam melakukan counter dengan menunjukkan kesadaran akan martabat dan harga diri mereka dalam bentuk munculnya jiwa kenegarawanan mereka lewat si aku lirik. Dia tidak hanya merepresentasikan diri sebagai si kulit hitam, tetapi juga sebagai si kulit putih yang miskin dan terpinggirkan, si kulit merah (etnik Indian) yang tidak diakui keberadannya sebagai pemilik tanah yang sah, sebagai 
seorang imigran yang mencari harapan baru di negara baru.

I am the poor white, fooled and pushed apart,

I am the Negro bearing slavery's scars.

I am the red man driven from the land,

I am the immigrant clutching the hope I seek-

And finding only the same old stupid plan

Of dog eat dog, of mighty crush the weak.

(baris 19-24)

Mereka secara sosial dihegemoni oleh etnik mayotitas Anglo-Amerika sehingga tidak memperoleh kesejehteraan ekonomi dan hak politik yang sama. Impian tinggal impian. Mereka tidak bisa berbuat apa pun juga. Nasib inilah yang sepanjang tahun mereka alami. Dalam situasi seperti ini, munculnya negarawan sangat diimpikan. Meskipun si aku lirik menunjukkan sifat ini dengan mewakili kelompok minoritas, termasuk minoritas kulit putih, ia tetap tidak berdaya menghadapi kekuatan besar mayoritas kulit putih.

Terlepas dari semua masalah yang ia hadapi, Si aku lirik tetap yakin bahwa Amerika akan tetap menjadi negara bebas yang ia impikan. Dengan menunjukkan partisipasinya sebagai warga Amerika, ia katakan bahwa suatu saat nanti impian itu pasti bisa ia rebut kembali. Hidup dalam kesetaraan hak dan kuajiban antarwarga negara akan dinikmati bersama antara etnik kulti hitam maupun kulit putih.

The land that's mine-the poor man's, Indian's, Negro's, ME-

Who made America,

Whose sweat and blood, whose faith and pain,

Whose hand at the foundry, whose plow in the rain,

Must bring back our mighty dream again. (baris 65-8)
Dalam puisi “Theme for English B", seperti yang telah dikutip sebelumnya bahwa etnik Afro-Amerika mendapat stigma sebagai manusia yang tidak beradab. Mere-ka tidak bisa diterima sebagai manusia yang utuh sempurna sebagaimana etnik kulit putih karena dianggap tidak bisa mencipta puisi yang menawarkan bahasa yang halus. Ketika mereka mencipta karya sastra, karya mereka digunakan sebagai sarana menentang rasisme dan stereotyping yang dikukan oleh etnis kulit putih sebagai pembuktian kesadaran mereka bahwa mereka juga makhluk yang memiliki martabat dan harga diri sebagaimana etnis kulit putih.

Dampak pengalaman masa perbudakan memunculkan identitas Afro-Amerika (Harlem Renaissance, 2012:par.16). Dengan membuat si Aku liris menciptakan puisi, Hughes ingin membuktikan kebenaran yang etniknya miliki. Mereka juga merupakan manusia seutuhnya sama seperti etnik lainnya yang mempunyai keinginan atau hasrat yang sama dan selera yang sama. Sebagai klimaksnya, si kulit hitam pun mampu juga menulis puisi.

Puisi merupakan ekpresi diri yang ditulis secara ekpersif, padat, dan penuh dengan muatan emosi penulis. Dengan demikian, Hughes ingin sampaikan bahwa puisi merupakan alat yang ia gunakan untuk mengekspresi kebenaran yang ia rasakan, dan sekaligus ingin tunjukkan bahwa ia mampu menghasilkan puisi sebagaimana bangsa kulit putih. Etnik Afro-Amerika bukan bangsa biadab.

\section{Jati Diri Kaum Afro-Amerika}

Berdasarkan bentuk-bentuk hegemoni etnik Anglo-Amerika dan respon etnik Afro-Amerika seperti telah diuraikan di atas, dapat dilihat cerminan jati diri etnik Afro-Amerika yang disuarakan melalui berbagai karya sastra yang menjadi subyek penelitian ini. Secara umum, jati diri yang menonjol di dalam tiga karya tersebut adalah adanya kesetaraan rasial 
etnik Afro-Amerika dengan etnik yang lain, terutama dengan etnik mayoritas. Sebagai warga negara seutuhnya yang memiliki hak dan kewajiban yang sama dengan warga negara lainnya. Munculnya kebanggaan akan identitas etnis AfroAmerika yang sesungguhnya menjadi potensi besar bagi Amerika terkait dengan keragaman etnis dan budayanya. Jati diri sebagai etnis yang memiliki potensi besar dalam mewujudkan cita-cita bangsa Amerika sebagai negara yang bebas.

Jati diri yang disampaikan dalam "I, Too, Sing America" adalah jati diri kesataraan rasial/ etnis. Bahwa etnik kulit hitam Afro-Amerika juga mempunyai kelas yang sama sebagaimana etnik kulit putih Anglo-Amerika. Warna kulit mereka bukan penanda inferioritas, 'hitam itu indah'. Dengan penuh kesadaran si aku lirik mengatakan bahwa bila semua aspek kehidupan ia yang miliki terpenuhi, ia pun akan tampak cantik secantik counterpart mereka,

\section{They'll see how beautiful I am}

And be ashamed-

I, too, am America

(baris 16-8).

Mereka menolak standar kecantikan seperti yang telah diindoktrinasikan oleh etnikAnglo-Amerika. Kecantikan hanya diukur oleh warna kulit. Etnik Anglo-Amerika pasti akan merasa malu bila akhirnya menyadari kecantikan yang dimiliki si kulit hitam.

Dalam puisi "Let America be America Again" sebagaimana dipaparkan di atas, tampak jelas bahwa jati diri yang ingin disampaikan oleh etnik Afro-Amerika adalah jati diri sebagai warga negara Amerika seutuhnya yang mempunyai hak dan kewajiban yang sama tanpa memandang warna kulit dan asal etnis. Dengan demikan tidak akan ada lagi diskriminasi sosial dari etnik tertentu atas etnik tertentu.
Sementara itu, dalam puisi "Theme for English B", Hughes membongkar kemunafikan serta sifat narrow-sighted etnik Anglo-Amerika. Mereka mengingkari kodrat manusia yang sacara filosofis setara. Baik etnik minoritas maupun mayoritas di Amerika yang beragama nasrani bersama-sama merayakan hari raya Natal. Agama merupakan kebutuhan batin yang hakiki bagi umat manusia. Hughes menunjukkan pula bahwa kalangan etnik Afro-Amerika memiliki selera tinggi yang sama terhadap musik yang dikatagorikan klasik dan hanya bisa dininkmati oleh kelas menengah ke atas etnik Anglo-Amerika. Namun, Hughes juga memperlihatkan bahwa etnik kulit hitam juga memiliki jenis musik dan musisi hebat setara dengan "Bach", yaitu "Bessie" dan jenis musik "bop".

Akhirnya Hughes mampu menutup luka lama yang secara turun-temurun diderita kaumnya, yaitu stigma sebagai bangsa tidak beradab. Hughes mampu menjadi penyair dan penulis sastra yang tidak bisa dipandang sebelah mata dalam khasanah sastra Amerika. Namanya melambung di antara penulis kulit putih. Hughes menghiasi lembar-lembar sejarah kehidupan bangsa Amerika karena prestasinya dalam dunia sastra dan pergerakan sosial-budaya yang ia lakukan bersama tokoh-tokoh Harlem lainnya. Hal ini disimbolkan lewat tokoh ciptaannya yang mampu menghasilkan puisi yang bersisi tentang kebenaran atas dirinya, dan tentu saja, atas kaumnya. Hughes menjadi orang Amerika besar tanpa menghilangkan jati dirinya sebagai bagian dari etnik AfroAmerika yang minoritas.

\section{SIMPULAN}

Berdasarkan hasil analisis yang telah diuraikan sebelumnya, dapat disimpulkan bahwa bentuk-bentuk hegemoni rasial etnik Anglo-Amerika terhadap etnik Afro-Amerika tergambarkan dengan jelas dalam ketiga puisi karya Hughes yang 
menjadi subyek penelitian ini. Hegemoni rasial etnik Anglo-Amerika muncul dalam bentuk stereotyping negatif terhadap etnik Afro-Amerika. Misalnya dalam hal yang berkaitan dengan penampilan fisik dengan muncul anggapan bahwa black is not beautiful; stigma bahwa etnik Afro-Amerika adalah etnik yang inferior, bodoh, dan tidak mampu menulis. Stereotyping negatif ini mengarah pada marjinalisasi terhadap etnik Afro-Amerika yang tercermin dalam ketidakadilan dan kesewenangan yang dilakukan oleh etnik mayoritas.

Dari berbagai bentuk hegemoni rasial yang tercermin di dalam ketiga karya yang menjadi sumber data penelitian ini, munculah respon dari etnik Afro-Amerika. Respon yang diberikan lebih menunjukkan nilai-nilai yang bermartabat sebagai manusia yang selama ini selalu dianggap tidak bermartabat. Respon tersebut cenderung menonjolkan keluhuran budi, akal sehat, dan jauh dari sifat destruktif yang terkait dengan kekerasan. Respon ini berbentuk kesadaran etnik Afro-Amerika akan martabat dan harga diri, serta kepercayaan diri mereka yang menjadi dasar akan eksistensi mereka di masyarakat yang didominasi etnik kulit putih, yang ditunjukkan dengan kebanggaan etnik, patriotisme, potensi intelektual, dan optimisme.

Adapun nilai jati diri yang bisa ditemukan adalah adanya kesadaran mengenai kesetaraan rasial etnik Afro-Amerika dengan etnik yang lain. Sebagai warga negara seutuhnya yang memiliki hak dan kewajiban yang sama dengan warga negara lainnya serta munculnya kebanggaan akan identitas etnis Afro-Amerika. Jati diri inilah yang menjadi potensi besar bagi Amerika terkait dengan keragaman etnis dan budayanya dalam mewujudkan cita-cita bangsa Amerika sebagai negara yang mengedepankan kesetaraan dalam kemajemukan.

\section{UCAPAN TERIMA KASIH}

Penelitian ini terlaksana atas bantuan dana dari Dikti melalui skema penelitian pengembangan dan pembinaan kelompok bidang keilmuan dengan dana Bantuan Operasional Perguruan Tinggi Negeri (BOPTN). Atas kesempatan yang diberikan diucapkan terima kasih. Demikian pula ucapan terima kasih disampaikan kepada pimpinan universitas, fakultas, jurusan, serta program studi di lingkungan Universitas Negeri Yogyakarta. Ucapan terimaksih juga disampaikan kepada rekan sejawat yang telah berkenan memberi masukan dan saran perbaikan penulisan artikel ini.

\section{DAFTAR PUSTAKA}

Ashcroft, Bill, Gareth Griffiths, \& Helen Tiffin. 1989. The Empire Writes Back: Theory and Practice in Post-Colonial Literatures. London \& New York: Routledge.

Bressler, Charles E. 1999. Literary Chriticism: An Introduction to Theory and Practice. Edisi ke-2. New Jersey: Prentice Hall.

Darma, Budi. 1993. "Novel dan Jatidiri" dalam Basis: Majalah Kebudayaan Umum. Juli-XLII-No.7. Yogyakarta: Yayasan B.P. Basis, hal. 241-56.

Gandhi, Leela. 2001. Teori Postkolonial: Upaya Meruntuhkan Hegemoni Barat. Diterjemahkan oleh Yuwan Wahyutri dan Nur Hamidah. Yogyakarta: Penerbit Qalam.

"Harlem Renaissance". 2011. http://en. wikipedia.org/wiki/Harlem_Renaissance. (Diunduh pada 2 September 2011).

Hughes, Langston. "I, Too, Sing Amerika". http://www.poemhunter.com/poem/ let-america-be-america-again/ (Diunduh pada 18 Maret 2011).

Hughes, Langston. "Let America Be America Agian"http://www.poets. org/viewmedia.php/ prmMID/15615. (Diunduh pada 18 Maret 2011). 
Hughes, Langston. Theme for English B". http://www.eecs.harvard.edu/ keith/ poems/English B.html. (Diunduh pada 18 Maret 2011).

Hughes, Langston. 1999. “The Negro Artist and The Racial Mountain 1926" In Hazel Arnett Ervin. Ed. African American Literary Criticism, 1773 to 2000. New York: Twayne Publishers

Kaat, Amanda. 2012. "Walt Whitman, Langston Hughes: Comparative Analysis." http://student.sheboyganfalls.k12.wi.us/14alkaat/2013/01/07/ walt-whitman-langston-hughes-comparative-analysis/. (Diunduh pada 6 November 2012).

Kohl, Herbert. 1992. From Archetype to Zeitgeist: Powerful Ideas for Powerful Thinking. Boston: Little, Brown and Company.

"Let America Be America Again Summary". http://romper20.hubpages. com/hub/Hughes-LangstonLetAmericaBeAmericaAgain (Diunduh pada 2 September 2012).
"New Negro". http://en.wikipedia.org/ wiki/New_Negro. (Diunduh pada 2 September 2011).

"Postcolonialism." 2008. http://www. enwikipedia.postcolonialism.html. (Diunduh pada 5 November 2012).

"Postcolonial Literature." 2008. http:// www.enwikipedia.postcolonialliterature.html (Diunduh pada 2 November 2012).

Rukhaya, M.K. 2012. “Poetry Analysis: Langston Hughes' "Theme for English $B^{\prime \prime \prime}$. http://www.squidoo.com. Diunduh 5 Nopember 2012.

Rhodes, Henry. 2007. "The Social Contributions of the Harlem Renaissance." http://www.yale.edu/ynhti/curriculum/units/1978/2/78.02.08.x.html (Diunduh pada 2 November 2012).

Tyson, Lois. 2006. Critical Theory Today: A User-Friendly Guide. Edisi ke-2. New York: Routledge.

Whitman, Walt. "I Hera America Singin". http://www.poets.org/viewmedia. php/prmMID/15752 (Diunduh pada 2 Maret 2012). 